\title{
Relative Effectiveness of Various Amendments in Improving Yield and Nutrient Uptake under Organic Crop Production
}

\author{
Sukhdev S. Malhi \\ Agriculture and Agri-Food Canada, Melfort, Canada. \\ Email: sukhdev.malhi@agr.gc.ca \\ Received July $5^{\text {th }}, 2012$; revised July $8^{\text {th }}, 2012$; accepted July $19^{\text {th }}, 2012$
}

\begin{abstract}
In organic farming, artificial/synthetic inorganic fertilizers/chemicals are not applied to increase crop yields, but adequate amounts of nutrients are essential for sustainable high production from agricultural crops. Two 3-year (2008wheat, 2009- pea, and 2010 - barley) field experiments were conducted on certified organic farms near Spalding (Dark Brown Chernozem - Typic Haploboroll) and Star City (Gray Luvisol-Typic Haplocryalf) in northeastern Saskatchewan to determine the relative effectiveness of various organic amendments (compost, alfalfa pellets, wood ash, rock phosphate, Penicillium bilaiae, MykePro, or gypsum), and intercropping of non-legume (wheat, barley) and legume (pea) annual crops on seed yield, total biomass yield (TBY) and nutrient uptake in seed + straw of wheat, pea and barley. In 2008, seed yield, TBY and nutrient uptake of wheat increased (but small) with compost and alfalfa pellets. In 2010, seed yield, TBY and nutrient uptake of barley increased substantially with compost and alfalfa pellets and moderately with wood ash. Other amendments had little or no effect on crop yield and nutrient uptake. In 2009, there was no beneficial effect of any amendment on yield and nutrient uptake of pea, most likely due to fixation of $\mathrm{N}$ which is the most limiting nutrient in these soils. Intercropping of wheat or barley with pea produced greater seed yield and nutrient uptake per unit land area basis compared to wheat or barley grown as sole crops in most cases. In conclusion, our results suggest potential benefits in improving yield and nutrient uptake of wheat and barley from compost, alfalfa pellets and possibly wood ash, most likely by preventing deficiencies of some nutrients, especially N, lacking in these soils under organic farming. Our findings also suggest the need for future research to determine the feasibility of rock phosphate, Penicillium bilaiae, MykePro, gypsum or other amendments in preventing $\mathrm{P}$ and/or S deficiency in organic crops using soils extremely deficient in these nutrients.
\end{abstract}

Keywords: Amendments; Barley; Nutrient Uptake; Organic; Pea; Wheat; Yield

\section{Introduction}

The interest and demand for organically-grown food and fiber are increasing in Canada [1] and internationally, because of possible high economic returns due to the price premiums on organically-grown products [2]. In organic farming, synthetic fertilizers/chemicals are not allowed to prevent nutrient deficiencies and increase crop production. However, adequate amounts of nutrients are essential for sustainable high production from agricultural crops, because any nutrient limiting in soil can cause substantial reduction in crop yield. The availability of plant nutrients to crops depends on crop species/cultivar, soil type and climatic conditions. In the Canadian Prairies, under organically farmed cropping systems most soils are deficient in available $\mathrm{N}$, many soils are low in available $\mathrm{P}$, and some soils contain insufficient amounts of available $\mathrm{S}$ (mostly in the Parkland region) and available $\mathrm{K}$ for optimum crop growth and yield [3,4]. Research comparing both organic and conventional cropping systems in Saskatchewan has suggested that on soils low in available $\mathrm{P}$, long-term production of organic crops without adding adequate amounts of $\mathrm{P}$ can result in the decrease/depletion of available $\mathrm{P}$ in soil by removing/ mining $\mathrm{P}$ in seed away from the field [5]. Recent research in Montana, USA [6] has also indicated the decrease in nutrients in organically managed soils, resulting in poor crop yield and produce quality. Therefore, maintaining soil fertility is an important production issue facing organic agriculture in the semi-arid region of the Canadian Prairies and elsewhere.

Because $\mathrm{N}$ is the most limiting/deficient nutrient in most soils for optimum yield, organic producers usually focus on increasing $\mathrm{N}$ availability and minimizing $\mathrm{N}$ de- 
ficiency in soil-crop system on organic farms by growing $\mathrm{N}$-fixing legume crops for grain, forge and/or green manure in the rotations $[7,8]$. However, if soils are deficient in available $\mathrm{P}, \mathrm{K}, \mathrm{S}$ or other essential nutrients, the only alternative is to use external organic sources to prevent these nutrient deficiencies, which can be inconvenient and/or expensive. For example, manure/compost can provide these nutrients to crops on organic farms, but often there is not enough manure to apply on all farm fields, especially in remote areas where the cost of transporting manure/compost to long distances can be uneconomical [9]. On such soils, rock phosphate fertilizer, elemental S fertilizer, gypsum, wood ash (wood ash is a waste product of forest industry that contains large amounts of $\mathrm{Ca}$ and $\mathrm{Mg}$, about $0.44 \% \mathrm{P}, 4.2 \% \mathrm{~K}, 1 \% \mathrm{~S}$, and small amounts of other essential nutrients) or some other amendments may be used to correct nutrient deficiencies in organic crops.

In addition, crop yields on organic farms can be increased (also called out-yielding) by intercropping nonlegume and legume annual crops together $[10,11]$. Outyielding (i.e. when the yield produced by an intercrop is greater than the yield produced by the component crops grown in monoculture on the same total land area) can be calculated by using Land Equivalency Ratio (LER), which is defined as the relative land area under sole crops that is required to produce yields equivalent to intercropping $[$ LER $=($ Intercrop1/Sole Crop1 $)+$ Intercrop2/ Sole Crop2)] as described by [12]. The LER values are used to compare growth/yield of intercrops relative to the respective sole crops. If the LER value is greater than 1 , it indicates that out-yielding is occurring with intercropping, and the intercrop is more productive than the component crops grown as sole crops (i.e. less land requirement with intercropping compared to sole crops). If the LER is lower than 1 , it suggests that there is no out-yielding occurring with intercropping (in fact underyielding with intercropping), and the intercrop is less productive than the sole crops.

The information on the efficacy of organic nutrient sources and intercropping non-legume and legume annual crops in increasing yield by preventing nutrient deficiencies in crops is lacking under Canadian prairie soil-climatic conditions, especially in the Parkland region. The main objective of our study was to determine the relative effectiveness of various amendments (compost, alfalfa pellets, wood ash, rock phosphate, Penicillium bilaiae, gypsum and MykePro), and intercropping of non-legume (wheat, barley) and legume (pea) annual crops on yield and nutrient uptake of wheat, pea or barley organic crops and soil quality/fertility in northeastern Saskatchewan. The residual effects of these amendments on organic $\mathrm{C}$ and $\mathrm{N}$, potentially mineralizable $\mathrm{N}\left(\mathrm{N}_{\min }\right)$ and available nutrients (N, P, K and S) in soil are published in a previous paper [13], and the effects of these amendments on crop yield and uptake of N, P, K and S in the present study are reported in this paper.

\section{Materials and Methods}

Two 3-year (2008-wheat, 2009-pea, and 2010 - barley) field experiments were established on certified organic farms in spring 2008 near Spalding (Dark Brown Chernozem-Typic Haploboroll) and Star City (Gray Luvisol-Typic Haplocryalf) in northeastern Saskatchewan. During the summer of 2007, the land was managed as tilled fallow in Experiment 1 at Spalding, and as green manure fallow in Experiment 2 at Star City. At Spalding, the land has been under certified organic farming practice for 21 years, with barley, hard red spring wheat, oat, fall rye, flax, lentil and pea generally grown in various rotations including green manure and/or summer fallow. At Star City, barley, hard red spring wheat, spelt wheat, oat, fall rye, flax, yellow mustard, polish canola, and pea have been usually grown in various rotations including green manure and/or summer fallow under certified organic farming practice for 15 years. Some characteristics of soils used in these experiments are presented in Table 1. Soil was low in available $\mathrm{N}$ at both sites. Based on soil type and agroecological region, the soil was suspected to be potentially deficient in available $\mathrm{P}$ in Experiment 1 at Spalding and available $S$ in Experiment 2 at Star City. Precipitation in the growing season (May, June, July and August) at the two sites from 2008 to 2010, and long-term (30-year) average of precipitation and air temperature in May to August at the nearest Environment Canada Meteorological Station (AAFC Melfort Research Farm) are presented in Table 2. The precipitation in the 2008 growing season was below average, with little precipitation in May. In 2009, the growing season precipitation was near long-term average, with slightly lower than average precipitation in May and slightly higher than average precipitation in August. In 2010, the growing season precipitation was much higher than average (especially in June, and also in April prior to spring), and relatively cooler air temperatures in most summer. A randomized complete block design was used to lay out the treatments in four replications. Each plot was $7.5 \mathrm{~m}$ long and $1.8 \mathrm{~m}$ wide.

In Experiment 1, the 23 treatments were: 1. Control (no amendment), 2. Compost @ $10 \mathrm{Mg} \cdot \mathrm{ha}^{-1}$, 3. Compost (a) $20 \mathrm{Mg} \cdot \mathrm{ha}^{-1}, 4$. Compost @ $30 \mathrm{Mg} \cdot \mathrm{ha}^{-1}, 5$. Wood ash (a) $1 \mathrm{Mg} \cdot \mathrm{ha}^{-1}, 6$. Wood ash@2 Mg ha ${ }^{-1}$, 7. Wood ash@ $3 \mathrm{Mg} \cdot \mathrm{ha}^{-1}$, 8. Rock phosphate granular@10 kg.P.ha ${ }^{-1}$, 9. Rock phosphate granular@20 kg $@ \cdot \cdot h a^{-1}, 10$. Rock phosphate granular@30 kg.P.ha ${ }^{-1}, 11$ Rock phosphate finely-ground @ $10 \mathrm{~kg} \cdot \mathrm{P} \cdot \mathrm{ha}^{-1}, 12$. Rock phosphate finely- 
Table 1. Some characteristics of soils of field experiments in spring 2008, 2009 and 2010 at Spalding and Star City in northeastern Saskatchewan.

\begin{tabular}{|c|c|c|c|c|c|c|c|c|c|c|}
\hline Site & Year & $\begin{array}{c}\text { Soil great } \\
\text { group }\end{array}$ & $\begin{array}{l}\text { Depth } \\
(\mathrm{cm})\end{array}$ & Texture $^{\mathrm{y}}$ & $\mathrm{pH}^{\mathrm{x}}$ & $\begin{array}{c}\text { Organic } \\
\text { matter }(\%)\end{array}$ & $\begin{array}{l}\text { Nitrate-N } \\
\left(\mathrm{mg} \cdot \mathrm{kg}^{-1}\right)\end{array}$ & $\begin{array}{c}\text { Extractable P } \\
\left(\mathrm{mg} \cdot \mathrm{kg}^{-1}\right)\end{array}$ & $\begin{array}{l}\text { Sulphate-S } \\
\left(\mathrm{mg} \cdot \mathrm{kg}^{-1}\right)\end{array}$ & $\begin{array}{l}\text { Extractable } \\
\mathrm{K}\left(\mathrm{mg} \cdot \mathrm{kg}^{-1}\right)\end{array}$ \\
\hline \multirow[t]{9}{*}{ Spalding } & 2008 & Dark Brown & $0-15$ & SL & 7.1 & 2.4 & 8.8 & 8.3 & 3.8 & 141 \\
\hline & & & $15-30$ & & & & 3.9 & 3.9 & 2.6 & 99 \\
\hline & & & $30-60$ & & & & 2.4 & 2.1 & 2.0 & 82 \\
\hline & 2009 & & $0-15$ & SL & nd & nd & 5.2 & 6.3 & 2.6 & 163 \\
\hline & & & $15-30$ & & & & 1.6 & 5.4 & 0.6 & 147 \\
\hline & & & $30-60$ & & & & 1.8 & 3.7 & 0.1 & 124 \\
\hline & 2010 & & $0-15$ & SL & nd & nd & 3.6 & 7.6 & 2.1 & 184 \\
\hline & & & $15-30$ & & & & 0.9 & 5.5 & 1.4 & 141 \\
\hline & & & $30-60$ & & & & 0.8 & 4.7 & 0.8 & 121 \\
\hline \multirow[t]{9}{*}{ Star City } & 2008 & Gray luvisol & $0-15$ & $\mathrm{~L}$ & 6.2 & 1.8 & 10.7 & 8.6 & 2.8 & 154 \\
\hline & & & $15-30$ & & & & 3.2 & 5.4 & 2.4 & 116 \\
\hline & & & $30-60$ & & & & 1.7 & 5.5 & 1.2 & 115 \\
\hline & 2009 & & $0-15$ & $\mathrm{~L}$ & nd & nd & 14.0 & 11.8 & 2.3 & 182 \\
\hline & & & $15-30$ & & & & 2.2 & 5.2 & 0.6 & 131 \\
\hline & & & $30-60$ & & & & 1.4 & 5.8 & 0.3 & 129 \\
\hline & 2010 & & $0-15$ & $\mathrm{~L}$ & nd & nd & 7.2 & 9.7 & 2.4 & 216 \\
\hline & & & $15-30$ & & & & 1.5 & 7.2 & 1.4 & 129 \\
\hline & & & $30-60$ & & & & 2.0 & 6.3 & 1.7 & 114 \\
\hline
\end{tabular}

${ }^{\mathrm{z}}$ Based on Canadian Soil Classification System. ${ }^{\mathrm{y}} \mathrm{SL}$ and L refer to sandy loam and loam, respectively; ${ }^{\mathrm{x}}$ nd refers to not done in 2009 and 2010 , as soil $\mathrm{pH}$ and organic matter do not change frequently in the absence of amendments.

Table 2. Growing season monthly and total precipitation for the four site-years, and average 30-yr average precipitation and temperature in northeastern Saskatchewan.

\begin{tabular}{|c|c|c|c|c|c|c|c|c|}
\hline \multirow{3}{*}{ Month } & \multicolumn{6}{|c|}{ Precipitation in the growing season $(\mathrm{mm})^{\mathrm{z}}$} & \multirow{2}{*}{\multicolumn{2}{|c|}{30 -yr average }} \\
\hline & \multicolumn{3}{|c|}{ Spalding } & \multicolumn{3}{|c|}{ Star City } & & \\
\hline & 2008 & 2009 & 2010 & 2008 & 2009 & 2010 & Precipitation (mm) & Temperature $\left({ }^{\circ} \mathrm{C}\right)$ \\
\hline May & 15.0 & 10.9 & 103.2 & 6.2 & 21.2 & 66.6 & 45.6 & 9.1 \\
\hline June & 29.0 & 91.8 & 130.0 & 32.0 & 46.6 & 113.2 & 65.8 & 16.9 \\
\hline July & 90.6 & 67.8 & 51.0 & 118.4 & 75.6 & 63.6 & 75.5 & 18.3 \\
\hline August & 31.2 & 82.0 & 83.0 & 21.6 & 81.6 & 56.8 & 56.8 & 19.6 \\
\hline Total & 165.8 & 252.5 & 367.2 & 178.2 & 225.0 & 300.2 & 243.7 & \\
\hline
\end{tabular}

${ }^{\mathrm{z}}$ At the nearest Environment Canada Meteorological Station (Muenster for Spalding and Melfort Research Farm for Star City).

ground @ $20 \mathrm{~kg} \cdot \mathrm{P} \cdot \mathrm{ha}^{-1}, 13$. Rock phosphate finelyground@30 kg.P.ha ${ }^{-1}, 14$. Alfalfa pellets@1 Mg ha ${ }^{-1}$, 15. Alfalfa pellets@2 Mg $\mathrm{ha}^{-1}, 16$. Alfalfa pellets @ 4 $\mathrm{Mg} \cdot \mathrm{ha}^{-1}, 17$. Alfalfa pellets @6 Mg.ha ${ }^{-1}, 18$. Control + inoculate seed with Penicillium bilaiae, 19. Rock phosphate granular@20 kg.P.ha ${ }^{-1}+$ inoculate seed with Penicillium bilaiae, 20. Rock phosphate finely-ground @ $20 \mathrm{~kg} \cdot \mathrm{P} \cdot \mathrm{ha}^{-1}+$ inoculate seed with Penicillium bilaiae, 21. Pulse (no amendment), 22. Cereal + pulse intercrop (no amendment), and 23. MykePro.
In Experiment 2, the 21 treatments were: 1. Control (no amendment),2. Compost @10 Mg ha ${ }^{-1}$, 3. Compost @ $20 \mathrm{Mg} \cdot \mathrm{ha}^{-1}$, 4. Compost @ $30 \mathrm{Mg} \cdot \mathrm{ha}^{-1}$, 5. Wood ash@ $1 \mathrm{Mg} \cdot \mathrm{ha}^{-1}, 6$. Wood ash @ $2 \mathrm{Mg} \cdot \mathrm{ha}^{-1}, 7$. Wood ash@3 $\mathrm{Mg} \cdot h a^{-1}, 8$. Alfalfa pellets@1 $\mathrm{Mg} \cdot \mathrm{ha}^{-1}$, 9. Alfalfa pellets@2 Mg $\cdot \mathrm{ha}^{-1}, 10$. Alfalfa pellets@ $4 \mathrm{Mg} \cdot \mathrm{ha}^{-1}, 11$. Alfalfa pellets@6 Mg.ha ${ }^{-1}, 12$. Gypsum@10 kg.S $\cdot \mathrm{ha}^{-1}$, 13. Gypsum @20 kg·S hha ${ }^{-1}, 14$. Pulse (no amendment), 15. Cereal + pulse intercrop (no amendment), 16. Control + inoculate seed with Penicillium bilaiae, 17. Rock pho- 
sphate finely-ground @ $20 \mathrm{~kg} \cdot \mathrm{P} \cdot \mathrm{ha}^{-1}, 18$. Rock phosphate finely-ground @ $20 \mathrm{~kg} \cdot \mathrm{P} \cdot \mathrm{ha}^{-1}+$ inoculate seed with Penicillium bilaiae, 19. Rock phosphate granular@20 $\mathrm{kg} \cdot \mathrm{P} \cdot \mathrm{ha} \mathrm{h}^{-1}, 20$. Rock phosphate granular@ $20 \mathrm{~kg} \cdot \mathrm{P} \cdot \mathrm{ha}^{-1}+$ inoculate seed with Penicillium bilaiae, and 21. Myke-Pro.

On average, compost contained $1.3 \% \mathrm{~N}, 0.64 \% \mathrm{P}$, $1.3 \%$ and $0.3 \% \mathrm{~S}$; alfalfa pellets had $2.9 \% \mathrm{~N}, 0.20 \% \mathrm{P}$, $2.5 \%$ and $0.2 \% \mathrm{~S}$; and wood ash contained $0.51 \% \mathrm{P}$, $4.5 \%$ and $1.3 \% \mathrm{~S}$. Rock phosphate contained $7.4 \% \mathrm{P}$ and gypsum had $12 \%$ S. Penicillium bilaiae and MykePro do not supply any nutrients directly to soil/plant, but these inoculants are applied to increase the release of $\mathrm{P}$ from soil and/or rock phosphate for plant uptake. The amendments were broadcast on soil surface and all plots were rotovated to a depth of about $8 \mathrm{~cm}$ few days prior to seeding. Plots were seeded with a double-disc press drill at $17.8 \mathrm{~cm}$ row spacing. In each plot, a $1.25 \mathrm{~m}$ wide by $7.0 \mathrm{~m}$ long strip was harvested with a plot combine to determine seed yield. Straw yield was calculated from two 1-m long rows, hand harvested from each plot. Sub samples of seed and straw were oven dried $\left(60^{\circ} \mathrm{C}\right)$, and analyzed for total $\mathrm{N}$ [14], total P [15], total K [16] and total S [17].

The data on each parameter were subjected to analyses of variance (ANOVA) using GLM procedure in SAS [18]. The least significant difference at $\mathrm{P} \leq 0.05\left(\mathrm{LSD}_{0.05}\right)$ was used to determine significant differences between treatment means. For the convenience of the readers, the results on treatments with wheat or barley intercropped with pea, or grown as sole crops without any amendment are reported and discussed separately. In all other amendment treatments, there was only one crop in a growing season, i.e., wheat in 2008, pea 2009, or barley in 2010 .

\section{Results}

\subsection{Experiment 1 at Spalding}

\subsubsection{Yield}

In 2008, seed yield of wheat increased with compost and tended to increase with alfalfa pellets at higher rates in the first year of application (Table 3). However, application of Penicillium bilaiae, rock phosphate fertilizer

Table 3. Seed yield and total biomass yield (TBY) of wheat (2008), pea (2009) and barley (2010) with various amendments applied annually in spring of 2008, 2009 and 2010 at Spalding, Saskatchewan (Experiment 1).

\begin{tabular}{|c|c|c|c|c|c|c|c|}
\hline \multicolumn{2}{|c|}{ Treatment } & \multicolumn{3}{|c|}{ Seed yield $\left(\mathrm{kg} \cdot \mathrm{ha}^{-1}\right)$} & \multicolumn{3}{|c|}{ TBY $\left(\mathrm{kg} \cdot \mathrm{ha}^{-1}\right)$} \\
\hline No. & Amendments & $\begin{array}{c}2008 \\
\text { wheat }\end{array}$ & $\begin{array}{c}2009 \\
\text { pea }\end{array}$ & $\begin{array}{c}2010 \\
\text { barley }\end{array}$ & $\begin{array}{c}2008 \\
\text { wheat }\end{array}$ & $\begin{array}{c}2009 \\
\text { pea }\end{array}$ & $\begin{array}{c}2010 \\
\text { barley }\end{array}$ \\
\hline 1 & Control (no amendment) & 1902 & 3423 & 1253 & 5930 & 5159 & 4267 \\
\hline 2 & Compost@10 Mg·ha ${ }^{-1}$ & 1927 & 3799 & 2385 & 5669 & 5774 & 5530 \\
\hline 3 & Compost@20 Mg·ha ${ }^{-1}$ & 2146 & 3179 & 2576 & 6657 & 5314 & 6100 \\
\hline 4 & Compost@30 Mg·ha ${ }^{-1}$ & 2189 & 3326 & 2874 & 6186 & 5541 & 6747 \\
\hline 5 & Wood ash@1 Mg·ha ${ }^{-1}$ & 1743 & 3198 & 1827 & 5634 & 5081 & 4034 \\
\hline 6 & Wood ash@2 Mg·ha ${ }^{-1}$ & 1847 & 3102 & 1779 & 5606 & 4938 & 4415 \\
\hline 7 & Wood ash@3 Mg·ha ${ }^{-1}$ & 1951 & 3027 & 1820 & 5786 & 4648 & 4511 \\
\hline 8 & Rock phosphate granular @10 kg $\cdot \mathrm{P} \cdot \mathrm{ha}^{-1}$ & 1635 & 3393 & 1601 & 5304 & 5239 & 3809 \\
\hline 9 & Rock phosphate granular@ $20 \mathrm{~kg} \cdot \mathrm{P} \cdot \mathrm{ha}^{-1}$ & 1757 & 3347 & 1526 & 5548 & 5213 & 3496 \\
\hline 10 & Rock phosphate granular@30 kg $9 \cdot \mathrm{h} \cdot \mathrm{ha}^{-1}$ & 1871 & 3051 & 1659 & 5527 & 4686 & 4336 \\
\hline 11 & Rock phosphate finely-ground @ $10 \mathrm{~kg} \cdot \mathrm{P} \cdot \mathrm{ha}^{-1}$ & 1717 & 3177 & 1203 & 5277 & 4903 & 3743 \\
\hline 12 & Rock phosphate finely-ground @ $20 \mathrm{~kg} \cdot \mathrm{P} \cdot \mathrm{ha}^{-1}$ & 1815 & 3252 & 1368 & 5654 & 5025 & 4047 \\
\hline 13 & Rock phosphate finely-ground @ $30 \mathrm{~kg} \cdot \mathrm{P} \cdot \mathrm{ha}^{-1}$ & 1880 & 3226 & 1283 & 5943 & 4849 & 3736 \\
\hline 14 & Alfalfa pellets@1 $\mathrm{Mgvha}^{-1}$ & 1817 & 2968 & 1432 & 5633 & 4732 & 4100 \\
\hline 15 & Alfalfa pellets@2 Mg·ha ${ }^{-1}$ & 1954 & 2787 & 1693 & 5822 & 4515 & 4406 \\
\hline 16 & Alfalfa pellets@4 Mg·ha ${ }^{-1}$ & 2083 & 2345 & 2174 & 6271 & 4171 & 5521 \\
\hline 17 & Alfalfa pellets@6 Mg·ha ${ }^{-1}$ & 2079 & 1785 & 2128 & 6814 & 3934 & 4566 \\
\hline 18 & Control + Penicillium bilaiae & 1823 & 3076 & 1306 & 5677 & 5013 & 3162 \\
\hline 19 & $\begin{array}{l}\text { Rock phosphate granular @ } 20 \mathrm{~kg} \cdot \mathrm{P} \cdot \mathrm{ha}^{-1}+ \\
\text { Penicillium bilaiae }\end{array}$ & 1853 & 3372 & 1534 & 5892 & 4821 & 3560 \\
\hline 20 & $\begin{array}{l}\text { Rock phosphate finely-ground @ } 20 \mathrm{~kg} \cdot \mathrm{P} \cdot \mathrm{ha}^{-1}+ \\
\text { Penicillium bilaiae }\end{array}$ & 1854 & 3150 & 1462 & 5934 & 4895 & 4144 \\
\hline \multirow[t]{3}{*}{23} & MykePro & 1896 & 3279 & 1412 & 5889 & 5132 & 3767 \\
\hline & $\operatorname{LSD}_{0.05}$ & 229 & 534 & 332 & 754 & 706 & 1090 \\
\hline & $\mathrm{SEM}^{\mathrm{Z}}$ & $80.9^{* * *}$ & $188.7^{* * *}$ & $117.0^{* * *}$ & $266.5^{*}$ & $249.5^{* *}$ & $383.7^{* * *}$ \\
\hline
\end{tabular}


without and with Penicillium bilaiae, and MykePro had no beneficial effect on seed yield of wheat, and seed yields were similar to the zero-amendment control. In 2009, there was no significant increase in seed yield of pea from the application of any amendment in the second year of application (Table 3). In fact, seed yield of pea decreased with increasing rate of alfalfa pellets. In 2010 , seed yield of barley increased considerably with compost, followed by alfalfa pellets especially at higher rates, and moderately with wood ash (Table 3). Seed yield of barley tended to increase (not significant) with granular rock phosphate, but seed yields in finely-ground rock phosphate, Penicillium bilaiae and MykePro treatments were similar to the control. Total biomass yield (TBY) usually followed response trends similar to seed yield, with increase in TBY from compost or alfalfa pellets but no consistent increase in TBY from wood ash and other amendments (Table 3).

\subsubsection{Nutrient Uptake}

In 2008, uptake of total N, K and S in seed + straw of wheat increased with application of alfalfa pellets at high rates (Tables 4 and 5). Total N, K and S uptake in seed + straw of wheat tended to increase with application of compost. This suggested that alfalfa pellets and possibly compost supplied $\mathrm{N}, \mathrm{K}$ and $\mathrm{S}$ for plant uptake in the first year of application. In 2009, total N, K and S uptake in seed + straw usually increased with compost, but no consistent effect from other amendments (Tables 4 and 5). In 2010, total $\mathrm{N}, \mathrm{K}$ and $\mathrm{S}$ uptake in seed + straw increased considerably with compost and moderately with alfalfa pellets, but no effect from other amendments (Tables 4 and 5). Total $P$ uptake in seed + straw of wheat in 2008 increased with increasing rate of alfalfa pellets and compost, but the increases were small and not significant (Table 4). In 2009, total P uptake in seed + straw of pea increased with application of compost, but decreased with increasing rate of alfalfa pellets (Table 4). In 2010, total P uptake of barley in seed + straw in- creased considerably with compost, but no consistent effect from other amendments (Table 4).

Table 4. Total $N$ and $P$ uptake in seed + straw of wheat (2008), pea (2009) and barley (2010) with various amendments applied annually in spring of 2008, 2009 and 2010 at Spalding, Saskatchewan (Experiment 1).

\begin{tabular}{|c|c|c|c|c|c|c|c|}
\hline \multicolumn{2}{|c|}{ Treatment } & \multicolumn{3}{|c|}{$\begin{array}{l}\text { Total N uptake in seed }+ \text { straw } \\
\qquad\left(\mathrm{kg} \cdot \mathrm{N} \cdot \mathrm{ha}^{-1}\right)\end{array}$} & \multicolumn{3}{|c|}{$\begin{array}{l}\text { Total P uptake in seed }+ \text { straw } \\
\qquad\left(\mathrm{kg} \cdot \mathrm{P} \cdot \mathrm{ha}^{-1}\right)\end{array}$} \\
\hline No. & Amendments & $\begin{array}{c}2008 \\
\text { wheat }\end{array}$ & $\begin{array}{c}2009 \\
\text { pea }\end{array}$ & $\begin{array}{c}2010 \\
\text { barley }\end{array}$ & $\begin{array}{c}2008 \\
\text { wheat }\end{array}$ & $\begin{array}{c}2009 \\
\text { pea }\end{array}$ & $\begin{array}{c}2010 \\
\text { barley }\end{array}$ \\
\hline 1 & Control (no amendment) & 51.2 & 127.7 & 41.1 & 10.1 & 13.0 & 10.3 \\
\hline 2 & Compost@10 Mg·ha ${ }^{-1}$ & 47.3 & 144.6 & 53.1 & 10.2 & 17.1 & 15.5 \\
\hline 3 & Compost@20 Mg.ha ${ }^{-1}$ & 54.3 & 137.8 & 60.9 & 11.8 & 18.0 & 16.0 \\
\hline 5 & Wood ash@1 Mg·ha ${ }^{-1}$ & 46.0 & 125.2 & 40.1 & 9.6 & 11.2 & 9.9 \\
\hline 6 & Wood ash@2 Mg·ha ${ }^{-1}$ & 50.2 & 116.1 & 42.0 & 9.7 & 10.1 & 10.5 \\
\hline 7 & Woodash@3 Mg·ha ${ }^{-1}$ & 50.7 & 113.2 & 41.8 & 9.3 & 10.2 & 11.0 \\
\hline 8 & Rock phosphate granular@10 kg·P·ha ${ }^{-1}$ & 43.3 & 129.9 & 38.4 & 8.6 & 12.4 & 9.4 \\
\hline 9 & Rock phosphate granular@20 kg·P·ha ${ }^{-1}$ & 45.7 & 126.3 & 36.4 & 8.3 & 11.2 & 8.8 \\
\hline 10 & Rock phosphate granular@30 kg·P·ha ${ }^{-1}$ & 51.6 & 111.2 & 44.7 & 9.3 & 9.3 & 9.3 \\
\hline 12 & Rock phosphate finely-ground @ $20 \mathrm{~kg} \cdot \mathrm{P} \cdot \mathrm{ha}^{-1}$ & 50.1 & 118.9 & 42.5 & 9.2 & 10.3 & 9.8 \\
\hline 13 & Rock phosphate finely-ground @30 kg $\cdot \mathrm{P} \cdot \mathrm{ha}^{-1}$ & 49.7 & 118.3 & 38.3 & 9.7 & 10.8 & 9.3 \\
\hline 14 & Alfalfa pellets@1 Mg·ha ${ }^{-1}$ & 49.8 & 105.2 & 41.1 & 9.3 & 10.1 & 9.3 \\
\hline 15 & Alfalfa pellets@2 Mg·ha ${ }^{-1}$ & 52.9 & 100.2 & 44.3 & 9.7 & 8.7 & 9.6 \\
\hline 16 & Alfalfa pellets@4 Mg·ha ${ }^{-1}$ & 62.6 & 89.7 & 56.3 & 10.8 & 8.3 & 11.7 \\
\hline 17 & Alfalfa pellets@6 Mg·ha ${ }^{-1}$ & 68.6 & 73.9 & 56.1 & 11.1 & 6.8 & 9.7 \\
\hline 18 & Control + Penicillium bilaiae & 48.5 & 117.4 & 35.6 & 9.2 & 10.3 & 8.0 \\
\hline 19 & Rock phosphate granular@20 kg $\cdot \mathrm{P} \cdot \mathrm{ha}^{-1}+$ Penicillium bilaiae & 49.3 & 121.4 & 37.5 & 9.9 & 11.1 & 8.3 \\
\hline 20 & $\begin{array}{l}\text { Rock phosphate finely-ground @ } 20 \mathrm{~kg} \cdot \mathrm{P} \cdot \mathrm{ha}^{-1}+ \\
\text { Penicillium bilaiae }\end{array}$ & 51.4 & 118.5 & 43.1 & 9.8 & 10.2 & 9.2 \\
\hline \multirow[t]{2}{*}{23} & MykePro & 52.9 & 118.7 & 39.8 & 10.1 & 11.0 & 9.1 \\
\hline & $\mathrm{LSD}_{0.05}$ & 7.3 & 20.8 & 9.2 & 1.6 & 3.2 & 2.5 \\
\hline
\end{tabular}

$\mathrm{z}^{* * *}$ refers to significant treatment effects in ANOVA at $\mathrm{P} \leq 0.001$. 
Table 5. Total $K$ and $S$ uptake in seed + straw of wheat (2008), pea (2009) and barley (2010) with various amendments applied annually in spring of 2008, 2009 and 2010 at Spalding, Saskatchewan (Experiment 1).

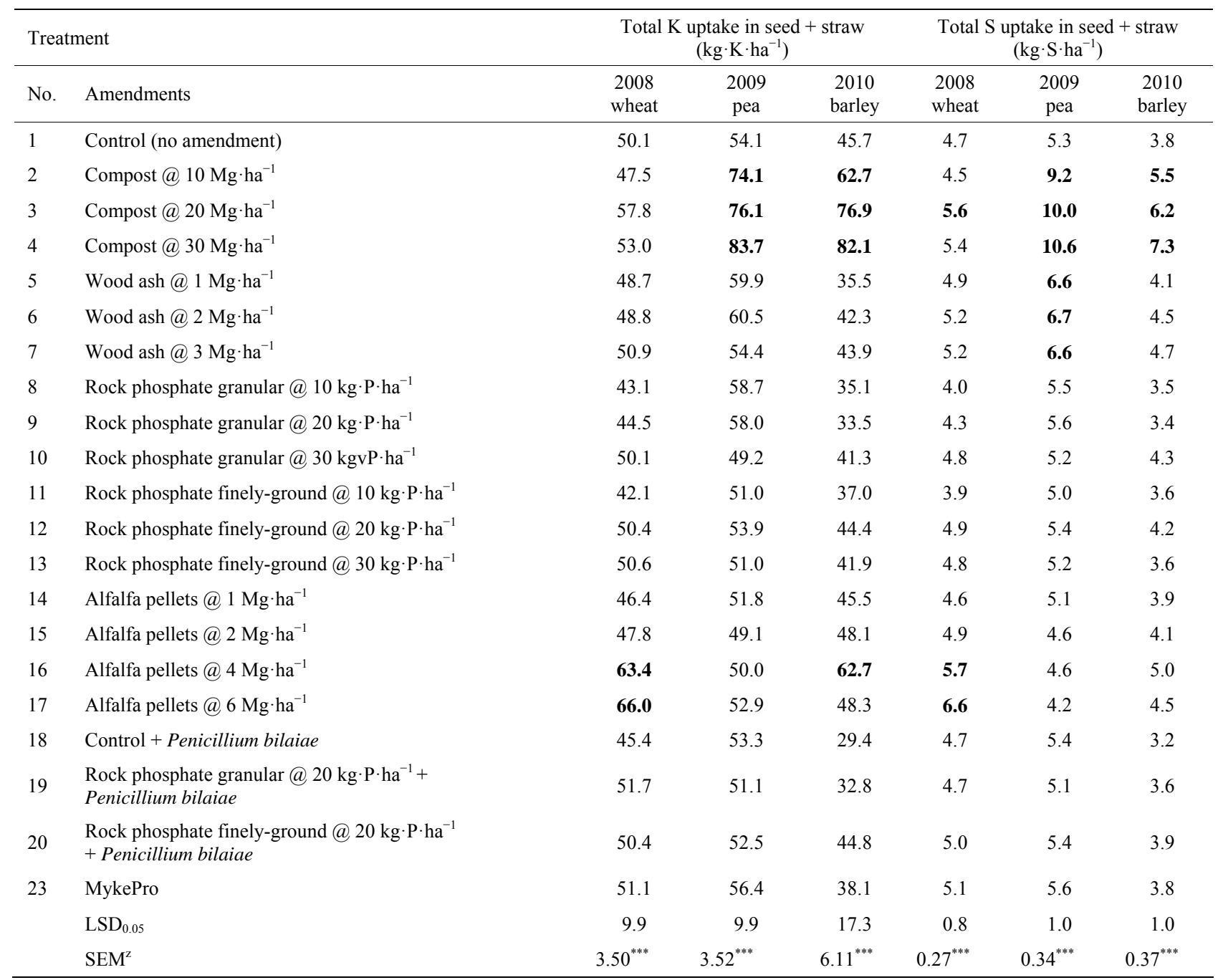

${ }^{z^{* * *}}$ refers to significant treatment effects in ANOVA at $\mathrm{P} \leq 0.001$.

\subsection{Experiment 2 at Star City}

\subsubsection{Yield}

In 2008, because of severe infestation of the experimental site with wild oat, seed yield of wheat was very low in all treatments (Table 6). Seed yield of wheat increased with application of compost and alfalfa pellets in most cases over the zero-amendment control, but there was little or no increase in seed yield with other amendments. The TBYs of wheat were moderately high, and there was a good response of TBY to compost, followed by alfalfa pellets and MykePro, but little or no increase from other amendments. In 2009, due to infestation with wild oat again, seed yields of pea were relatively low, but TBYs were fairly high (Table 6). Both seed yield and TBY of pea increased only with application of compost over the control. In 2010, seed yield and TBY of barley increased considerably with application of compost and alfalfa pellets over the control (Table 6). There was also an improvement in seed yield and TBY of barley (small, but significant) with application of wood ash at high rates. Seed yield of wild oat was higher in treatments receiving compost and alfalfa pellets compared to the control in all three years (data not shown).

\subsubsection{Nutrient Uptake}

In 2008 and 2009 , total $\mathrm{N}, \mathrm{P}, \mathrm{K}$ and $\mathrm{S}$ uptake in seed + straw increased with increasing rate of compost and also increased with alfalfa pellets at high rates (Tables 7 and 8). In 2010, total N, P, K and S uptake of barley in seed + straw increased considerably with application of compost and alfalfa pellets over the zero-amendment control (Tables 7 and 8). There was also a tendency of increase in total N, P, K and S uptake in seed + straw of barley 
Table 6. Seed yield and total biomass yield (TBY) of wheat (2008), pea (2009) and barley (2010) with various amendments applied annually in spring of 2008, 2009 and 2010 at Star City, Saskatchewan (Experiment 2).

\begin{tabular}{|c|c|c|c|c|c|c|c|}
\hline \multirow[b]{2}{*}{ No. } & \multirow[b]{2}{*}{ Amendments } & \multicolumn{3}{|c|}{ Seed yield $\left(\mathrm{kg} \cdot \mathrm{ha}^{-1}\right)$} & \multicolumn{3}{|c|}{ TBY $\left(\mathrm{kg} \cdot \mathrm{ha}^{-1}\right)$} \\
\hline & & $\begin{array}{l}2008 \\
\text { wheat }\end{array}$ & $\begin{array}{c}2009 \\
\text { pea }\end{array}$ & $\begin{array}{c}2010 \\
\text { barley }\end{array}$ & $\begin{array}{c}2008 \\
\text { wheat }\end{array}$ & $\begin{array}{c}2009 \\
\text { pea }\end{array}$ & $\begin{array}{c}2010 \\
\text { barley }\end{array}$ \\
\hline 1 & Control (no amendment) & 264 & 668 & 2233 & 3237 & 4893 & 5005 \\
\hline 2 & Compost@ $10 \mathrm{Mg} \cdot \mathrm{ha}^{-1}$ & 435 & 796 & 3359 & 3905 & 5546 & 7501 \\
\hline 3 & Compost@20 Mg·ha ${ }^{-1}$ & 470 & 965 & 3570 & 4611 & 5360 & 8216 \\
\hline 4 & Compost@30 Mg $\cdot \mathrm{ha}^{-1}$ & 580 & 1180 & 3671 & 5069 & 6379 & 8126 \\
\hline 5 & Wood ash@1 Mg·ha ${ }^{-1}$ & 305 & 765 & 2348 & 3897 & 4574 & 4831 \\
\hline 6 & Wood ash@2 Mg $\cdot \mathrm{ha}^{-1}$ & 341 & 760 & 2705 & 3695 & 5009 & 5489 \\
\hline 7 & Wood ash@3 Mg·ha ${ }^{-1}$ & 315 & 791 & 2804 & 3980 & 5030 & 6230 \\
\hline 8 & Alfalfa pellets@ $1 \mathrm{Mg} \cdot \mathrm{ha}^{-1}$ & 377 & 493 & 2663 & 3909 & 3901 & 5716 \\
\hline 9 & Alfalfa pellets@ $2 \mathrm{Mg} \cdot \mathrm{ha}^{-1}$ & 340 & 585 & 2872 & 3837 & 4565 & 5863 \\
\hline 10 & Alfalfa pellets@ $9 \mathrm{Mg} \cdot \mathrm{ha}^{-1}$ & 400 & 629 & 3859 & 4032 & 4782 & 8441 \\
\hline 11 & Alfalfa pellets@6 Mg·ha ${ }^{-1}$ & 429 & 726 & 4067 & 4322 & 5747 & 9577 \\
\hline 12 & Gypsum@10 kg·S·ha ${ }^{-1}$ & 391 & 758 & 2110 & 3855 & 4421 & 4540 \\
\hline 13 & Gypsum@20 kg·S·ha ${ }^{-1}$ & 328 & 633 & 2103 & 3750 & 4480 & 4685 \\
\hline 16 & Control + Penicillium bilaiae & 319 & 691 & 2128 & 3635 & 3635 & 4638 \\
\hline 17 & Rock phosphate finely-ground @ $20 \mathrm{~kg} \cdot \mathrm{P} \cdot \mathrm{ha}^{-1}$ & 271 & 619 & 2170 & 3116 & 4292 & 4720 \\
\hline 18 & $\begin{array}{l}\text { Rock phosphate finely-ground @ } 20 \mathrm{~kg} \cdot \mathrm{P} \cdot \mathrm{ha}^{-1}+ \\
\text { Penicillium bilaiae }\end{array}$ & 317 & 663 & 2133 & 3987 & 4639 & 4761 \\
\hline 19 & Rock phosphate granular@ $@ 20 \mathrm{~kg} \cdot \mathrm{P} \cdot \mathrm{ha}^{-1}$ & 317 & 592 & 2323 & 3719 & 4198 & 5020 \\
\hline 20 & Rock phosphate granular@20 kg $\cdot \mathrm{P} \cdot \mathrm{ha}^{-1}+$ Penicillium bilaiae & 347 & 589 & 2227 & 3775 & 4138 & 4772 \\
\hline \multirow[t]{3}{*}{21} & MykePro & 341 & 626 & 2202 & 4245 & 4195 & 4342 \\
\hline & $\mathrm{LSD}_{0.05}$ & 92 & 221 & 367 & 834 & 903 & 941 \\
\hline & $\mathrm{SEM}^{\mathrm{z}}$ & $32.3^{* * *}$ & $77.9^{* * *}$ & $129.3^{* * *}$ & $294.1^{*}$ & $318.4^{* * *}$ & $331.9^{* * *}$ \\
\hline
\end{tabular}

$\mathrm{z}^{*}$ and ${ }^{* * *}$ refer to significant treatment effects in ANOVA at $\mathrm{P} \leq 0.05$ and $\mathrm{P} \leq 0.001$, respectively.

Table 7. Total $N$ and $P$ uptake in seed + straw of wheat (2008), pea (2009) and barley (2010) with various amendments applied annually in spring of 2008, 2009 and 2010 at Star City, Saskatchewan (Experiment 2).

\begin{tabular}{|c|c|c|c|c|c|c|c|}
\hline \multicolumn{2}{|c|}{ Treatment } & \multicolumn{3}{|c|}{$\begin{array}{l}\text { Total N uptake in seed }+ \text { straw } \\
\qquad\left(\mathrm{kg} \cdot \mathrm{N} \cdot \mathrm{ha}^{-1}\right)\end{array}$} & \multicolumn{3}{|c|}{$\begin{array}{l}\text { Total P uptake in seed }+ \text { straw } \\
\left(\mathrm{kg} \cdot \mathrm{P} \cdot \mathrm{ha}^{-1}\right)\end{array}$} \\
\hline No. & Amendments & 2008 wheat & 2009 pea & 2010 barley & 2008 wheat & 2009 pea & 2010 barley \\
\hline 1 & Control (no amendment) & 34.6 & 46.5 & 57.7 & 4.6 & 6.7 & 13.1 \\
\hline 2 & Compost@10 Mg.ha & 42.0 & 57.0 & 76.8 & 6.3 & 9.3 & 19.8 \\
\hline 3 & Compost@20 Mg·ha ${ }^{-1}$ & 44.0 & 62.5 & 84.4 & 7.9 & 10.5 & 22.4 \\
\hline 4 & Compost@30 Mg·ha ${ }^{-1}$ & 48.8 & 75.0 & 89.4 & 8.9 & 12.8 & 23.8 \\
\hline 5 & Wood ash@1 Mg·ha ${ }^{-1}$ & 38.9 & 48.9 & 51.1 & 5.2 & 7.3 & 13.8 \\
\hline 6 & Wood ash@2 Mg·ha ${ }^{-1}$ & 35.7 & 52.5 & 56.9 & 5.4 & 8.3 & 15.0 \\
\hline 7 & Wood ash@3 Mg·ha ${ }^{-1}$ & 41.7 & 51.3 & 64.4 & 6.0 & 7.9 & 16.5 \\
\hline 8 & Alfalfa pellets@1 Mg $\mathrm{ha}^{-1}$ & 39.2 & 36.6 & 63.4 & 5.0 & 5.7 & 15.0 \\
\hline 9 & Alfalfa pellets@2 Mg $\cdot \mathrm{ha}^{-1}$ & 38.1 & 43.3 & 66.9 & 5.7 & 6.6 & 15.3 \\
\hline 10 & Alfalfa pellets@4 Mg.ha ${ }^{-1}$ & 42.7 & 47.6 & 94.9 & 5.4 & 6.8 & 19.5 \\
\hline 11 & Alfalfa pellets@6 Mg.ha ${ }^{-1}$ & 49.4 & 62.5 & 114.6 & 6.6 & 7.8 & 21.4 \\
\hline 12 & Gypsum@10 kg·S·ha ${ }^{-1}$ & 41.1 & 48.0 & 55.1 & 5.7 & 6.4 & 12.7 \\
\hline 13 & Gypsum@20 kg·S·ha ${ }^{-1}$ & 36.0 & 43.9 & 53.8 & 4.8 & 6.5 & 13.0 \\
\hline 16 & Control + Penicillium bilaiae & 34.6 & 40.8 & 53.1 & 4.5 & 5.9 & 13.1 \\
\hline 17 & Rock phosphate finely-ground@20 kg·P·ha ${ }^{-1}$ & 29.3 & 43.7 & 53.2 & 4.2 & 6.9 & 13.2 \\
\hline 18 & $\begin{array}{l}\text { Rock phosphate finely-ground @ } 20 \mathrm{~kg} \cdot \mathrm{P} \cdot \mathrm{ha}^{-1}+ \\
\text { Penicillium bilaiae }\end{array}$ & 35.4 & 45.7 & 54.7 & 5.9 & 8.0 & 13.9 \\
\hline 19 & Rock phosphate granular@ $20 \mathrm{~kg} \cdot \mathrm{P} \cdot \mathrm{ha}^{-1}$ & 31.5 & 40.4 & 55.2 & 5.5 & 6.9 & 14.1 \\
\hline 20 & Rock phosphate granular@ $20 \mathrm{~kg} \cdot \mathrm{P} \cdot \mathrm{ha}^{-1}+$ Penicillium bilaiae & 37.5 & 39.6 & 52.6 & 5.4 & 6.6 & 13.6 \\
\hline 21 & MykePro & 40.4 & 43.2 & 52.4 & 6.2 & 7.0 & 13.1 \\
\hline & $\mathrm{LSD}_{0.05}$ & 8.7 & 9.6 & 10.6 & 1.4 & 1.5 & 2.1 \\
\hline & $\mathrm{SEM}^{\mathrm{z}}$ & $3.07^{* * *}$ & $3.37^{* * *}$ & $3.73^{* * *}$ & $0.50^{* * *}$ & $0.52^{* * *}$ & $0.74^{* * *}$ \\
\hline
\end{tabular}

$\mathrm{z}^{* * *}$ refers to significant treatment effects in ANOVA at $\mathrm{P} \leq 0.001$. 
Table 8. Total $K$ and $S$ uptake in seed + straw of wheat (2008), pea (2009) and barley (2010) with various amendments applied annually in spring of 2008, 2009 and 2010 at Star City, Saskatchewan (Experiment 2).

\begin{tabular}{|c|c|c|c|c|c|c|c|}
\hline \multicolumn{2}{|c|}{ Treatment } & \multicolumn{3}{|c|}{$\begin{array}{l}\text { Total K uptake in seed }+ \text { straw } \\
\qquad\left(\mathrm{kg} \cdot \mathrm{K} \cdot \mathrm{ha}^{-1}\right)\end{array}$} & \multicolumn{3}{|c|}{$\begin{array}{l}\text { Total S uptake in seed }+ \text { straw } \\
\qquad\left(\mathrm{kg} \cdot \mathrm{S} \cdot \mathrm{ha}^{-1}\right)\end{array}$} \\
\hline No. & Amendments & $\begin{array}{l}2008 \\
\text { wheat }\end{array}$ & $\begin{array}{c}2009 \\
\text { pea }\end{array}$ & $\begin{array}{c}2010 \\
\text { barley }\end{array}$ & $\begin{array}{c}2008 \\
\text { wheat }\end{array}$ & $\begin{array}{c}2009 \\
\text { pea }\end{array}$ & $\begin{array}{c}2010 \\
\text { barley }\end{array}$ \\
\hline 1 & Control (no amendment) & 48.0 & 77.4 & 40.1 & 3.1 & 5.1 & 5.4 \\
\hline 2 & Compost@10 Mg·ha ${ }^{-1}$ & 49.5 & 93.4 & 71.0 & 3.9 & 12.6 & 7.5 \\
\hline 3 & Compost@20 Mg·ha ${ }^{-1}$ & 56.0 & 96.9 & 89.0 & 4.7 & 13.3 & 8.5 \\
\hline 4 & Compost@30 Mg·ha ${ }^{-1}$ & 64.2 & 123.5 & 88.5 & 4.8 & 16.9 & 8.6 \\
\hline 5 & Wood ash@1 Mg·ha ${ }^{-1}$ & 56.3 & 76.5 & 38.2 & 4.5 & 8.5 & 5.1 \\
\hline 6 & Wood ash@2 Mg·ha ${ }^{-1}$ & 53.3 & 87.3 & 45.2 & 4.0 & 10.8 & 5.9 \\
\hline 7 & Wood ash@3 Mg·ha ${ }^{-1}$ & 54.1 & 87.4 & 54.3 & 4.8 & 11.5 & 6.5 \\
\hline 8 & Alfalfa pellets@1 Mg·ha ${ }^{-1}$ & 54.0 & 62.7 & 48.1 & 3.7 & 4.3 & 5.8 \\
\hline 10 & Alfalfa pellets@4 Mg·ha ${ }^{-1}$ & 58.6 & 83.9 & 79.3 & 3.9 & 4.9 & 8.0 \\
\hline 11 & Alfalfa pellets@6 Mg $\mathrm{ha}^{-1}$ & 59.9 & 111.6 & 109.3 & 4.4 & 5.8 & 9.3 \\
\hline 12 & Gypsum@10 kg·s·ha ${ }^{-1}$ & 52.2 & 70.9 & 39.2 & 4.1 & 6.4 & 5.4 \\
\hline 13 & Gypsum@20 kg·s·ha ${ }^{-1}$ & 50.3 & 74.6 & 38.7 & 3.9 & 8.5 & 5.8 \\
\hline 16 & Control + Penicillium bilaiae & 46.5 & 55.1 & 37.3 & 3.2 & 3.8 & 4.8 \\
\hline 17 & Rock phosphate finely-ground @20 kg.P.ha ${ }^{-1}$ & 37.8 & 66.1 & 37.2 & 2.8 & 4.7 & 4.8 \\
\hline 18 & $\begin{array}{l}\text { Rock phosphate finely-ground @ } 20 \mathrm{~kg} \cdot \mathrm{P} \cdot \mathrm{ha}^{-1}+ \\
\text { Penicillium bilaiae }\end{array}$ & 48.0 & 74.9 & 41.7 & 3.2 & 4.8 & 5.0 \\
\hline 19 & Rock phosphate granular@20 kg·P·ha ${ }^{-1}$ & 47.4 & 66.9 & 42.9 & 3.2 & 4.3 & 5.1 \\
\hline 20 & Rock phosphate granular@ $20 \mathrm{~kg} \cdot \mathrm{P} \cdot \mathrm{ha}^{-1}+$ Penicillium bilaiae & 50.3 & 66.4 & 38.2 & 3.6 & 4.8 & 5.0 \\
\hline \multirow[t]{2}{*}{21} & MykePro & 57.5 & 70.8 & 36.4 & 4.0 & 4.3 & 4.8 \\
\hline & $\mathrm{SEM}^{\mathrm{z}}$ & $6.22^{\mathrm{ns}}$ & $6.59^{* * *}$ & $4.22^{* * *}$ & $0.35^{* * *}$ & $0.79^{* * *}$ & $0.32^{* * *}$ \\
\hline
\end{tabular}

$\mathrm{z}^{* * *}$ and ns refer to significant treatment effects in ANOVA at $\mathrm{P} \leq 0.001$ and not significant, respectively.

with wood ash. The results suggested that N, P, K and S in compost and alfalfa pellets became available to the crop in all three growing seasons. There was no increase in total $\mathrm{N}$ uptake in seed + straw from the application of other amendments.

\subsection{Cereal-pea Intercropping}

\subsubsection{Experiment 1 at Spalding}

At Spalding, seed yield was lower with pea alone, but greater with wheat alone than wheat-pea intercrop in 2008 (Table 9). The order of seed yield was pea alone $<$ wheat + pea intercrop $<$ wheat alone. The LER for wheat-pea intercrop was $1.08(0.62+0.46)$, suggesting $8 \%$ less land requirement for wheat-pea intercrop compared to wheat or pea grown as sole crops to produce the same seed yield. In 2009, barley alone and barley intercropped with pea produced lower seed yield than the pea alone (Table 9). The order of seed yield was pea alone $>$ barley + pea intercrop $>$ barley alone. The LER for barley-pea intercrop was $0.96(0.42+0.54)$, suggesting slightly higher land requirement for barley-pea intercrop compared to barley or pea grown as sole crops for the same seed yield. In 2010, seed yield of pea alone was highest, followed by barley-pea intercrop, with the lowest seed yield with barley alone (Table 9). The LER for barley-pea intercrop was $1.29(0.73+0.56)$. This suggests $29 \%$ lower land requirement for barley-pea intercrop compared to barley or pea grown as sole crops for the same seed yield. The total biomass yield of various crops in all three years usually showed trends similar to seed yield (Table 9).

\subsubsection{Experiment 2 at Star City}

At Star City, seed yields were very low due to severe wild oat infestation in 2008, and the order of seed yield was pea alone $<$ wheat + pea intercrop $=$ wheat alone (Table 10). The LER for wheat-pea intercrop was 1.22 $(0.68+0.54)$, suggesting $22 \%$ less land requirement for wheat-pea intercrop compared to wheat or pea grown as 
Table 9. Seed yield and total biomass yield (TBY - seed + straw) of wheat, barley, or pea grown as sole crops and as intercrop (wheat-pea in 2008, and barley-pea in 2009 and 2010) without addition of any amendment in 2008, 2009 and 2010 at Spalding, Saskatchewan (Experiment 1).

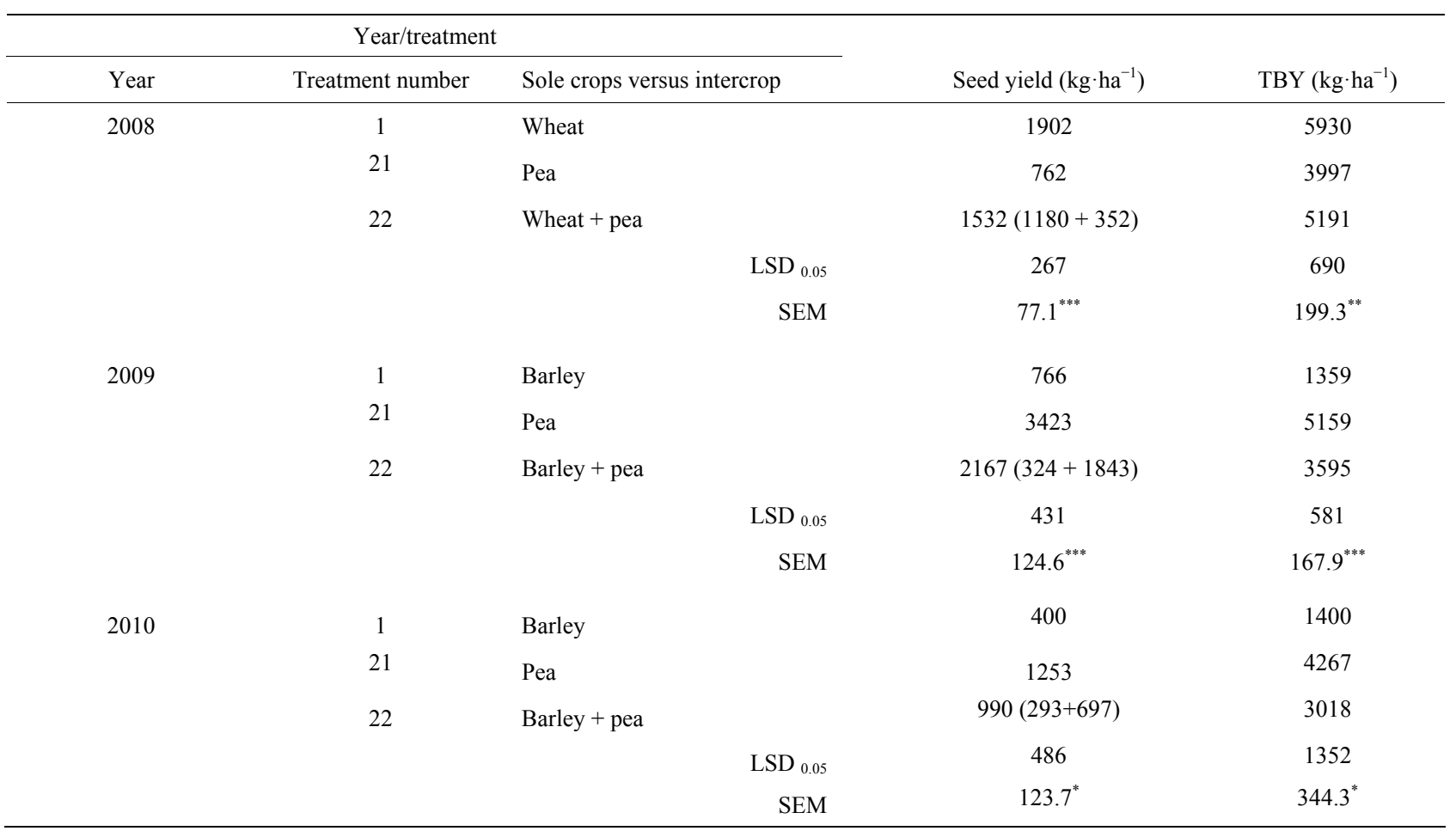

${ }^{* * *}{ }^{*}$ and ${ }^{* * *}$ refer to significant treatment effects in ANOVA at $\mathrm{P} \leq 0.10, \mathrm{P} \leq 0.05, \mathrm{P} \leq 0.01$ and $\mathrm{P} \leq 0.001$, respectively.

Table 10. Seed yield and total biomass yield (TBY - seed + straw) of wheat, barley, or pea grown as sole crops and as intercrop (wheat-pea in 2008, and barley-pea in 2009 and 2010) without addition of any amendment in 2008,2009 and 2010 at Star City, Saskatchewan (Experiment 2).

\begin{tabular}{|c|c|c|c|c|c|}
\hline \multicolumn{4}{|c|}{ Year/treatment } & \multirow[b]{2}{*}{ Seed yield $\left(\mathrm{kg} \cdot \mathrm{ha}^{-1}\right)$} & \multirow[b]{2}{*}{ TBY $\left(\mathrm{kg} \cdot \mathrm{ha}^{-1}\right)$} \\
\hline Year & Treatment number & Sole crops ve & & & \\
\hline \multirow[t]{5}{*}{2008} & 1 & Wheat & & 264 & 3237 \\
\hline & 14 & Pea & & 71 & 3635 \\
\hline & 15 & Wheat + pea & & $217(179+38)$ & 3829 \\
\hline & & & $\operatorname{LSD}_{0.05}$ & 66 & 836 \\
\hline & & & SEM & $19.2^{* *}$ & $241.7^{\mathrm{ns}}$ \\
\hline \multirow[t]{5}{*}{2009} & 1 & Barley & & 1409 & 3799 \\
\hline & 14 & Pea & & 668 & 4893 \\
\hline & 15 & Barley + pea & & $886(389+497)$ & 4372 \\
\hline & & & $\operatorname{LSD}_{0.05}$ & 242 & 1004 \\
\hline & & & SEM & $69.8^{* * *}$ & $290.1^{\bullet}$ \\
\hline \multirow[t]{5}{*}{2010} & 1 & Barley & & 2233 & 4905 \\
\hline & 14 & Pea & & 2399 & 5005 \\
\hline & 15 & Barley + pea & & $2569(1234+1335)$ & 4952 \\
\hline & & & $\operatorname{LSD}_{0.05}$ & 859 & 1519 \\
\hline & & & SEM & $248.3^{\text {ns }}$ & $439^{\mathrm{ns}}$ \\
\hline
\end{tabular}

\footnotetext{
$,^{* * *},{ }^{* * *}$ and ns refer to significant treatment effects in ANOVA at $\mathrm{P} \leq 0.10, \mathrm{P} \leq 0.01, \mathrm{P} \leq 0.001$ and not significant, respectively.
} 
sole crops to produce same seed yield. In 2009, barley alone produced greater, but barley intercropped with pea produced lower seed yield than the pea alone control (Table 10). The order of seed yield was barley alone > barley + pea intercrop $>$ pea alone. The LER for barleypea intercrop was $0.93(0.35+0.58)$, suggesting slightly higher land requirement for barley-pea intercrop compared to barley or pea grown as sole crops for the same seed yield. In 2010, seed yield of barley-pea intercrop tended to be higher than sole crops of barley and pea (Table 10). The LER for barley-pea intercrop was 1.11 $(0.55+0.56)$. This suggested that barley-pea intercrop had $11 \%$ lower land requirement compared to barley or pea grown as sole crops for the same seed yield. The total biomass yield showed trends similar to seed yield (Table 10).

\section{Discussion}

Earlier studies have shown potential beneficial effects of both organic and mineral/inorganic amendments (that are allowed as nutrient sources for certified organic production), and soil activators/inoculants on crop yields, produce quality and nutrient uptake [7,19-22]. Similarly, in our study a few amendments improved yield and nutrient uptake of crops grown on certified organic farms, and the results are discussed in detail by providing ex- planations in the following paragraphs.

Previous research has indicated that composted manure is a good supplier of N, P, K, S, and other nutrients, and is expected to increase crop yield when these nutrients are limiting in soil for optimum crop growth/development [23]. Similarly, in our study, composted manure and alfalfa pellets in many cases and also wood ash in some cases were effective in increasing crop yields in 2008 and 2010, when cereals were the test crops, and nutrient uptake in all years regardless of crop type. The increases in crop yields from various amendments were most likely by preventing some nutrient deficiencies in crops, especially $\mathrm{N}$ (the most yield limiting nutrient in soil at our experimental sites), as also suggested for manure by other researchers [23]. For alfalfa pellets, it is possible that narrow $\mathrm{C}: \mathrm{N}$ ratio in plant materials of alfalfa pellets may have supplied $\mathrm{N}$ and other nutrients after mineralization [24]. In our other previous study for the same experimental sites on residual effects of amendments on soil properties [13], total and light fraction organic $\mathrm{C}$ and $\mathrm{N}, \mathrm{N}_{\min }$, and available $\mathrm{N}, \mathrm{P}, \mathrm{K}$ or $\mathrm{S}$ in soil usually increased after three annual applications of compost, alfalfa pellets, wood ash or gypsum, depending on the amendment and site. Therefore, the increases in uptake of $\mathrm{N}, \mathrm{P}, \mathrm{K}$ or $\mathrm{S}$ in crops in the present study were due to the fact that these amendments supplied these nutrients for plant uptake, most likely by increasing nutrient availability in soil due to improvement in soil fertility and also possibly by enhancing soil quality/tilth/health.

Crops with taproots can absorb nutrients from deeper soil layers [25], depending on the root length [26]. However, if the surface and sub-soil layers are low in available $\mathrm{P}$, then it is very difficult to increase the availability of $\mathrm{P}$ on the farm site and sustain high crop production under organic farming systems, by using deep taproot crops in the rotation to bring $\mathrm{P}$ from deeper soil layers to the surface soil for future crop use [5]. So, the only alternative is to add external $\mathrm{P}$ source, which is acceptable and practical under organic farming. For example, previous research has suggested the use of vesiculararbuscular mychorrhiza (VAM), Penicillium bilaiae, rock phosphate, or bone meal to increase the release of $P$ from soil and organic $\mathrm{P}$ fertilizers/amendments in order to prevent $\mathrm{P}$ deficiency in $\mathrm{P}$-deficient soils and increase crop yields [19,21-22,27-28]. In a field study in Saskatchewan, Takeda [25] did not find any benefit of rock phosphate application on crop yield and $\mathrm{P}$ uptake over two years at any of the three sites, but showed increases in crop yield and $\mathrm{P}$ uptake at two sites from the application of rock phosphate in a combination with Penicillium bilaiae. Gleddie et al. [29] also reported positive responses to Penicillium bilaiae inoculation on soils that were extremely deficient in P for optimum growth. However, in our study on organic farms, there was no consistent significant beneficial effect of rock phosphate and/or Penicillium bilaiae on crop yield and P uptake in our study (with potentially P-deficient soil in Experiment 1) over three years. It is possible that our soils may not be deficient in available $P$ to the level to limit crop yield under organic production, because of the possibility of low yield potential under organic farming, as suggested by Brandt et al. [23] when comparing organic and conventional cropping systems over 12 years. We expected increase in crop yield and/or P uptake from the finely ground rock phosphate, because of the increase in surface area, but it did not happen. As explained earlier, this could be due to low yield potential of organic crops, and possibly the finely ground rock phosphate may have also conferred physical or chemical changes in soil, which in turn may have affected the microbiological activities in soil. This may have resulted in immobilization/fixation of $\mathrm{P}$ from finely ground rock phosphate into the soil organic fraction and subsequently impacting plant growth negatively on this potentially low P soil. Thus, suggesting the need of future long-term investigation to determine the efficacy of rock phosphate, Penicillium bilaiae, MykePro and other amendments in preventing deficiency of $\mathrm{P}$ in organic crops on soils extremely deficient in available $\mathrm{P}$ for optimum yield.

Like $\mathrm{P}$, if soil is low in available $\mathrm{S}$, then the only al- 
ternative is to add external S source that can be used under organic farming. Our previous research has suggested that gypsum can be a suitable source of $\mathrm{S}$ to prevent $\mathrm{S}$ deficiency in crops [30]. However, in our present study on organic farm, there was little effect of gypsum used in Experiment 2 (with potentially S-deficient soil at this site) on crop yield and $S$ uptake in any of the three years. It is possible that our soil may not be deficient in available $S$ to the extent that can limit crop yield, because of the low yield potential of crops in our study under organic farming and also lower $\mathrm{S}$ requirements of cereals than oilseeds. This suggests the need of future research to determine the feasibility of gypsum and other amendments (such as granular elemental S) in preventing S deficiency in organic crops on soils extremely deficient in available $\mathrm{S}$ for optimum crop growth and yield. In our study, wood ash increased yield of barley in both experiments in 2010, and this may be due to the supply of $\mathrm{P}, \mathrm{S}$, or other nutriaents to the crop, because it contains fairly high content of available $\mathrm{P}, \mathrm{S}, \mathrm{K}, \mathrm{Ca}$ and $\mathrm{Mg}$, but little or no $\mathrm{N}$.

In 2009, there was no beneficial effect on seed yield and/or nutrient uptake of pea from any amendment in Experiment 1 (in fact, seed yield and nutrient uptake of pea decreased with increasing rate of alfalfa pellets in this experiment), and only from compost application in Experiment 2. This was most likely that pea can fix $\mathrm{N}$ from the atmospheric air for its own requirement $[8$, 31-33] and do not need any $\mathrm{N}$ (probably the most limiting nutrient in soil at these sites) from external sources. Thus, suggesting little or no increase in yield of pea from $\mathrm{N}$-supplying organic amendments, especially when soil is adequately supplied with $\mathrm{P}, \mathrm{S}, \mathrm{K}$, or other nutrients and legume is the main crop. When legumes are grown in the rotation, it is also possible that their crop residue after decomposition may also provide $\mathrm{N}$ benefit to subsequent crops for improving yield under organic farming [32,34]. In Experiment 1, we did not expect any dramatic reduction in seed yield of pea from alfalfa pellets application treatments compared to the control. The decrease in seed yield of pea with increasing rate of alfalfa pellets was most likely due to the increase in wild oat infestation as evidenced by the significant increase in seed yield of wild oat with increasing rate of alfalfa pellets (data not shown; seed yield of wild oat ranged from 122 to 317 $\left.\mathrm{kg} \cdot \mathrm{ha}^{-1}\right)$.

Previous research has suggested yield on organic farms can be increased (also called out-yielding calculated as LER) by intercropping non-legume and legume annual crops together compared to as sole crops for cereal-legume [10,11]. Similarly, in our study, the LER values were greater than 1 in the cereal-pea intercrop treatments compared to the wheat, barley, or pea as sole crops in 2 of the 3 years. This indicates less land requirement for wheat- or barley-pea intercrop compared to wheat, barley, or pea grown as sole crops to produce the same seed yield. This also suggests the importance of growing intercrops in improving productivity and use efficiency of land and soil nutrients, while sustaining high crop production.

\section{Conclusion}

There was some potential benefit in improving yield and nutrient uptake of wheat and barley from compost, alfalfa pellets and possibly wood ash, and from intercropping non-legume wheat or barley with legume pea. Our findings suggest the need for future research to determine the feasibility of rock phosphate, Penicillium bilaiae, MykePro, gypsum or other amendments in preventing $\mathrm{P}$ and/or $\mathrm{S}$ deficiency in organic crops using soils extremely deficient in these nutrients.

\section{Acknowledgements}

The author thanks Western Alfalfa for financial assistance and supplying alfalfa pellets amendment for this study, International Compost Ltd., Calgary, Alberta, for supplying Rock Phosphate fertilizers for this study, and D. Leach and K. Strukoff for technical help.

\section{REFERENCES}

[1] A. Macey, "Certified Organic Production in Canada," Canadian Organic Growers, 2005. http://www.cog.ca

[2] R. P. Zentner, P. Basnyat, S. A. Brandt, A. G. Thomas, D. Ulrich, C. A. Campbell, C. N. Nagy, B. Frick, R. Lemke, S. S. Malhi and M. R. Fernandez, "Input Management and Crop Diversity: Effects on Economic Returns and Riskiness of Cropping Systems in the Semiarid Canadian Prairie," Renewable Agricultural Food Systems, Vol. 26, No. 3, 2011, pp. 1-16. doi:10.1017/S1742170510000591

[3] M. H. Entz, R. Guilford and R. Gulden, "Crop Yield and Soil Nutrient Status on 14 Organic Farms in the Eastern Part of the Northern Great Plains," Canadian Journal of Plant Science, Vol. 81, No. 2, 2001, pp. 351-354. doi:10.4141/P00-089

[4] C. A. Watson, P. Atkinson, P. Gosling, L. R. Jackson and F. W. Ryans, "Managing Soil Fertility in Organic Farming Systems," Soil Use and Management, Vol. 18, 2002, pp. 239-247. doi:10.1079/SUM2002131

[5] S. S. Malhi, S. A. Brandt, R. Lemke, A. P. Moulin and R. P. Zentner, "Effects of Input Level and Crop Diversity on Soil Nitrate-N, Extractable P, Aggregation, Organic C and N, and N and P Balance in the Canadian Prairie," Nutrient Cycling in Agroecosystems, Vol. 84, No. 1, 2009, pp. 1-22. doi:10.1007/s10705-008-9220-0

[6] P. R. Miller, D. E. Buschena, C. A. Jones and J. A. Holmes, "Transition from Intensive Tillage to No-Tillage and Organic Diversified Cropping Systems," Agronomy Journal, Vol. 100, No. 3, 2009, pp. 591-599. doi:10.2134/agronj2007.0190 
[7] R. P. Zentner, C. A. Campbell, V. O. Biederbeck, F. Selles, R. Lemke, P. G. Jefferson, and Y. Gan, "LongTerm Assessment of Management of an Annual Legume Green Manure Crop for Fallow Replacement in the Brown Soil Zone," Canadian Journal of Plant Science, Vol. 84, No. 1, 2004, pp. 11-22. doi:10.4141/P02-188

[8] N. Z. Lupwayi and Y. K. Soon, "Nitrogen Release from Field Pea Residue and Soil Inorganic $\mathrm{N}$ in a Pea-Wheat Crop Rotation in Northwestern Canada," Canadian Journal of Plant Science, Vol. 89, No. 2, 2009, pp. 239246. doi:10.4141/CJPS08019

[9] J. J. Schoenau, "The Value of Manure," Proceedings of Manure Management 2000 Conference, 28 June 2000, Calgary, 2000, pp. 2-5.

[10] R. Paolini, F. Caporali and E. Campiglia, "Yield Response, Complementarity and Competitive Ability of Bread Wheat (Triticum aestivum L.) and Pea (Pisum sativum L.) in Mixtures," Agricoltura Mediterranea, Vol. 123, No. 2, 1993, pp. 114-121.

[11] H. Hauggaard-Nielsen and E. S. Jensen, "Evaluating Pea and Barley Cultivars for Complementarity in Intercropping at Different Levels of Soil N Availability," Field Crops Research, Vol. 72, No. 3, 2001, pp. 185-196. doi:10.1016/S0378-4290(01)00176-9

[12] A. R. Szumigalski and R. C. Van Acker, "Land Equivalent Ratios, Light Interception, and Water Use in Intercrops in the Presence or Absence of In-Crop Herbicides," Agronomy Journal, Vol. 100, No. 4, 2008, pp. 1145-1154. doi:10.2134/agronj2006.0343

[13] S. S. Malhi, "Short-Term Residual Effects of Various Amendments on Organic C and N, and Available Nutrients in Soil under Organic Crop Production," Agricultural Sciences, Vol. 3, No. 3, 2012, pp. 375-384.

[14] R. J. Noel and L. G. Hambleton, "Collaborative Study of a Semi-Automated Method for the Determination of Crude Protein in Animal Feeds," Journal of Association of Official Analytical Chemists, Vol. 59, 1976, pp. 134140.

[15] W. F. Milbury, V. T. Stack and F. L. Doll, "Simultaneous Determination of Total Phosphorus and Total Kjeldahl Nitrogen in Activated Sludge with the Technicon Continuous Digestor System," In: Technicon International Congress, Advances in Automatic Analysis, Industrial Analysis, Vol. 2, 1970, pp. 299-304.

[16] J. A. Varley, "Automated Method for the Determination of Nitrogen, Phosphorus and Potassium in Plant Material," Analyst, Vol. 91, No. 1079, 1966, pp. 119-126. doi:10.1039/an9669100119

[17] J. B. Jones, "Plant Tissue Analysis in Micronutrients," In: SSSA, Chapter 13, Micronutrients in Agriculture, 2nd Edition, SSSA Book Series 4, ICP, Private Communication with Technical Personnel, Questron Technologies Corp, Mississauga, 1991.

[18] SAS Institute, "Online Documentation for SAS, Version $8, " 2004$. http://support.sas.com/documentation/onlinedoc/index.html

[19] R. M. N. Kucey, "Increased Phosphorus Uptake by Wheat and Field Beans Inoculated with a Phosphorus-Solubi- lizing Penicillium bilaji Strain and with Vesicular-Arbuscular Mycorrhizal Fungi," Applied Environmental Microbiology, Vol. 53, 1987, pp. 2699-2703.

[20] R. E. Blackshaw, "Nitrogen Fertilizer, Manure, and Compost Effects on Weed Growth and Competition with Spring Wheat," Agronomy Journal, Vol. 97, No. 6, 2005, pp. 1612-1621. doi:10.2134/agronj2005.0155

[21] P. M. Chalk, R. F. Souze, B. J. R. Urquiaga and R. M. Boddey, "The Role of Arbuscular Mychorrhiza in Legume Sybiotic Performance," Soil Biology and Biochemistry, Vol. 38, No. 9, 2006, pp. 2944-2951. doi:10.1016/j.soilbio.2006.05.005

[22] A. S. Jeng, T. K. Haraldsen, R. Gronlund and P. A. Pedersen, "Meat and Bone Meal as Nitrogen and Phosphorus Fertilizer to Cereals and Ryegrass," Nutrient Cycling in Agroecosystems, Vol. 76, No. 2-3, 2009, pp. 183-191. doi:10.1007/s10705-005-5170-y

[23] S. A. Brandt, R. P. Zentner, O. O. Olfert, A. G. Thomas and S. S. Malhi, "Input Level and Crop Diversity Strategies to Enhance Sustainability of Crop Production and Soil Quality in the Northern Great Plains of North America," In: S. S. Malhi, Y. Gan, J. J. Schoenau, R. L. Lemke and M. A. Liebig, Eds., Recent Trends in Soil Science and Agronomy Research in the Northern Great Plains of North America, Research Signpost (2010), Trivandrum, Chapter 8, 2010, pp. 179-199.

[24] W. O. Enwezor, "The Mineralization of Nitrogen and Phosphorus in Organic Materials of Varying C:N and C:P Ratios," Plant and Soil, Vol. 44, No. 1, 1976, pp. 237-240. doi:10.1007/BF00016972

[25] M. H. Entz, W. J. Bullied, D. A. Foster, R. Gulden and K. Vessey, "Extraction of Subsoil Nitrogen by Alfalfa, Alfalfa-Wheat and Perennial Grass Systems," Agronomy Journal, Vol. 93, No. 3, 2001, pp. 495-503. doi:10.2134/agronj2001.933495x

[26] S. D. Merrill, D. L. Tanaka and J. D. Hanson, "Root Length Growth of Eight Crop Species in Haplustoll Soils," Soil Science Society of America Journal, Vol. 66, No. 3, 2002, pp. 913-923.

[27] M. Takeda, "Solubilization of Rock Phosphate by Penicillium bilaiae: Mechanisms and the Feasibility for Use in Organic Crop Production," Master's Thesis, University of Saskatchewan, Saskatoon, 2004.

[28] R. L. Walker, C. A. Wattson, R. M. Rees and E. A. Stockdale, "Managing Soil Fertility in Organic Farming Systems," Aspects of Applied Biology, Vol. 79, 2006, pp. 300-315.

[29] S. C. Gleddie, D. Schlechte and G. Turnbull, "Effect of Inoculation with Penicillium bilaii (Provide ${ }^{(B)}$ ) on Phosphate Uptake and Yield of Canola in Western Canada," Proceedings of Alberta Soil Science Workshop, Edmonton, 22-24 February 1993, pp. 155-160.

[30] S. S. Malhi, K. Heier and E. Solberg, "Effectiveness of Elemental S Fertilizers on Forage Grasses," Canadian Journal of Plant Science, Vol. 80, No. 1, 2000, pp. 105112. doi:10.4141/P99-002

[31] M. Badaruddin and D. W. Meyer, "Grain Legume Effects on Soil Nitrogen, Grain Yield, and Nitrogen Nutrition of 
Wheat," Crop Science, Vol. 34, No. 5, 1994, pp. 13041309. doi:10.2135/cropsci1994.0011183X003400050030x

[32] H. J. Beckie and S. A. Brandt, "Nitrogen Contribution of Field Pea in Annual Cropping Systems. 1. Nitrogen Residual Effect," Canadian Journal of Plant Science, Vol. 77, No. 3, 1997, pp. 311-322. doi:10.4141/P96-161

[33] L. E. Welty, L. S. Prestbye, R. E. Engel, R. A. Larson, R. H. Lokerman, R. S. Speilman, J. R. Sims, L. I. Hart, G. D.
Kushnak and A. L. Dubbs, "Nitrogen Contribution of Annual Legumes to Subsequent Barley Production," Applied Agricultural Research, Vol. 3, No. 2, 1988, pp. 98-104.

[34] D. W. A. Przednowek, M. H. Entz, B. Irvine, D. N. Flate and J. R. Thiessen Martens, "Rotational Yield and Apparent N Benefits of Grain Legumes in Southern Manitoba," Canadian Journal of Plant Science, Vol. 84, No. 4, 2004, pp. 1093-1096. doi:10.4141/P04-032 